\title{
The Clinical Practice's Case. Syndrome of Megacytolysis at the Patient with the Ischemic Stroke
}

\author{
Iryna Gayova ${ }^{1}$, Iryna Romash ${ }^{1}$, Ivan Romash ${ }^{2}$, Neogi Reevu $^{3}$ \\ ${ }^{1}$ Department of Propaedeutics of Internal Medicine, Ivano-Frankivsk National \\ Medical University (IFNMU), Ivano-Frankivsk, Ukraine \\ ${ }^{2}$ Department of Psychiatry, Narcology and Medical Psychology, Ivano-Frankivsk \\ National Medical University (IFNMU), Ivano-Frankivsk, Ukraine \\ ${ }^{3} \mathrm{GD}$ Hospital and Diabetes Institute, Kolkata, India
}

\begin{abstract}
Resume. The Clinical Practice's Case. A patient V., the woman of 73 years old, was diagnosed an ischemic stroke. At her tests were detected extremely high AsAT, AlAT and polycystic liver and kidneys. Data of ECG, bilirubins and creatinin were normal. The patient had been taken Paracetamol for last year to reduce artralgia. Paracetamol was excluded and complex treatment administered. The patient discharged from hospital with improvement and the normal data of AsAT, AlAT.
\end{abstract}

Keywords. Ischemic Stroke, Megasyndrome of Cytolysis, Polycystic liver and kidneys, Paracetamol, Heptral.

The Clinical Practice's Case. A patient V., the woman of 73 years old, complained of a severe weakness and dizziness. She suffered from arterial hypertension (AH). The patient had been taken Paracetamol for last year to reduce artralgia. Examination: the patient's condition was moderate. Her position was an active. She coud walk herself. She answered the questions properly. Her skin and visible mucous membranes were pale and clean. Vesicular auscultation was heard over her lungs. The cardiac tones were rhythmical, the heart rate was 77 per $1 \mathrm{~min}$, pulse - 77 per $1 \mathrm{~min}$,

$\mathrm{BP}=165 / 85 \mathrm{~mm} \mathrm{Hg}$. Her tongue was moist and clean. Her abdomen was soft and painless. Her liver's sizes after Kurlov: $I=14 \mathrm{~cm}, I I=10 \mathrm{~cm}$, III $=9 \mathrm{~cm}$. Her urination and defecation were normal, the ordinary colors of urine and feces. Peripheral edema was absent. Pasternatskyi's symptom was negative on both sides.

The clinical diagnosis: $\mathrm{AH}$, stage III, hypertensive crises complicated with the ischemic stroke, degree 3, extremely high risk of complications. Ischemic heart disease. Cardiosclerosis diffuse. HF-II-B, FC-III. 
The laboratory and instrumental investigations' results. Blood test: platelets - 176,0 g/l, bands $-23 \%$, ESR- $23 \mathrm{~mm} / \mathrm{hr}$. Biochemical blood test. Common bilirubin - 14,9 mcmol/1, AlAT- 340,6 Un/1, AsAT- 805,0 Un/1, urea $12,3 \mathrm{mM} / 1$, basic phosphatase - $160 \mathrm{Un} / 1$, alfa-amilase - 9,1 mg/s 1, glucose in blood - 5,5 mmol/1. Blood test for the markers of viral hepatitis: HBsAg (-), HCVAb (-). Lipidogram: LPLD - 3,54 mmol/1. Serological blood test (-). Ordinary urine test: protein - 0,678g in $650,0 \mathrm{ml}$, or $1 \mathrm{~g} / 1$ (normal amount - less than $0,002 \mathrm{~g} / 1$ ); erythrocytes $-8-10$, transformed. Ultrasound investigation of abdominal organs: Polycystic liver. Hepatomegaly. Chronic cholecystites. Chronic pancreatitis. Polycystic kidneys. ECG: rhythm is sinusal, correct, HR-77 per $1 \mathrm{~min}$. ECG-signs of left ventricular hypertrophy.

The mentioned case has been noticed when the physician was called to department of vascular neurology for consultation. The neurologist explained the patient's diagnosis that was confirmed by CT and could not be unclear. The patient's granddaughter, the doctor herself, was present in department and worried about the excessively high AsAT and AlAT's levels at her grandmother. The test could not be unclear as it was doubled: AlAT - 340,6 Un/1 (normal 0-36 Un/1), AsAT- 805,0 Un/1 (normal 0-34 Un/l). Taking the case history the physician has got information that both members of family, the patient's son and granddaughter suffer from Gilbert's syndrome.

The results of ultrasound investigation of abdominal organs and kidneys. Liver, right lobe - 17,9 cm (normal size 14-15cm), left lobe - 5,8cm (normal 3-4cm), square lobe $-5,8 \mathrm{~cm}$. There are multiply cysts in the left lobe, their diameters are equal from $1,0 \mathrm{~cm}$ till $2,3 \mathrm{~cm}$; the cysts' diameter in the right lobe $-4,8 \mathrm{~cm}, 9,6$ $\mathrm{cm}, 1,9 \mathrm{~cm}$; vena porta $1,0 \mathrm{~cm}$, diffusely tight. On the border of right lobe and left lobe - Echo (-) 2,5cm. There are calcinates in the liver's structure. Gallbladder: V$29 \mathrm{ml}$, no stones, the cervix is bent. The walls are tight. Pancreas - hyperechogenic diffusely, the head $2,5 \mathrm{~cm}$, the body $2,5 \mathrm{~cm}$, the tale $2,7 \mathrm{~cm}$. The spleen - ordinary. Right kidney - 11,1 x 15,2cm, parenchyma 1,0cm, in parenchyma there is Echo (-) $1,8 \mathrm{~cm}$ in diameter, in the middle segment there is a group of Echo (-) 1,5$1,8 \mathrm{~cm}$ in diameter. Left kidne $11,5 \times 15,7 \mathrm{~cm}$, parenchyma $1,0 \mathrm{~cm}$, in the middle segment there are the cysts $2,2 \mathrm{cmm}, 2,0 \mathrm{~cm}, 2,8 \mathrm{~cm}$, in the kidney's gate there are Echo (-) 6,0-4,3 cm, and there are calcinates in parenchyma. Conclusion: 
Polycystic liver. Hepatomegaly. Chronic cholecystites. Chronic pancreatitis. Polycystic kidneys. The structural changes of liver and renal parenchyma.

Results and discussion. When it is difficult to make the diagnosis I read the laboratory tests again. So, in urine test: protein $-0,678 \mathrm{~g}$ in $650,0 \mathrm{ml}$ or $1 \mathrm{~g} / 1$ (normal - less than $0,002 \mathrm{~g} / 1$ ); erythrocytes $8-10$, transformed. Not only protein had been filtrated into urine, but the red blood cells also. At the same time, creatinin's level is normal. And there was no one renal disease in the past. Except polycystic kidneys. And I start thinking about that renal cysts - in case of an extreme their thinning due to long-termed intake of Paracetamol - does hematuria could be appeared? Yes, it could be possible. When the cyst is bordering on renal pelvis, glomerule, tubule, per diapedesum. And an increased AsAT could confirm such suggestion? Yes.

Return to liver now. Syndrome of megacytolysis means for the hepatocytes, first: hepatic coma, necrosis. But the patient is active. Secondly, at the patient should develop hepatic jaundice but her skin, visible mucous membranes, urine and feces are naturally colored and bilirubin's level is normal. Thence, I make conclusion: cytolis could not has come from hepatocytes. In the hepatic cysts (their amount was huge, doctor could not calculate them exactly, the maximal cyst reached $9,6 \mathrm{~cm}$ in diameter) took place the same pathological thinning of their mucous membranes that demonstrated itself by syndrome of megacytolysis, superhigh AsAT. (Ivashkin V.T.,2009; Perederii V.H.,2012).

An increased level of basic phosphatase $160 \mathrm{Un} / 1$ (normal $42-141 \mathrm{Un} / \mathrm{l}$ ) does confirm the syndrome of intra-hepatic cholestasis due to presence of multiply cysts in the liver (Andruschenko E.V., 1985; Mostovyi Yu.M.,2009).

More side effects of Paracetamol have been found: thrombocytopenia $176 \mathrm{~g} / 1$, the increased levels of alfa-amylaze - 9,1 мг/с л (normal 3,3-8,9 mg/c 1) and urea 12,3mM/1 (while normal range 2,5-8,2 mM/1) ( Ivashkin V.T.,2009; 2010).

The physician prescribed Heptral 400mg, dissolved in 5,0ml standard solvent, intravenously slowly, the first 5 days, the next 20 days - Tab. Heptral 400mg, 1 tablet twice per day. (Iurev K.L.,2012; Babak O.Ya.,2015).

The patient was discharged from hospital with improvement. The levels of AsAT and AlAT were nomal, AsAT-25,0 Un/1, AlAT- 36,0 Un/l. 
Conclusion. The side - effects of Paracetamol have appeared at the patient V., after a year of Paracetamol's uncontrolled intake: syndrome of megacytolysis, syndrome of cholestasis; the increased levels of alfa-amylaze and urea; thrombocytopenia; proteinuria, hematuria.

\section{References:}

Andruschenko E.V. (1985) Differential-diagnostic reference book of therapist. Kiev, "Zdorov'ya“, 295s.

Babak O.Ya., Lapshina E.A., Babak M.O., Chernyak A.N. (2015) Liver disease treatment strategy. The role and place of ademetionine from the perspective of evidencebased medicine. Suchasna gastroenterologIya, 1,30-33.

Ivashkin V.T., A.O.Bueverov. (2010) Pathogenetic and clinical rationale for the use of ademetionine in the treatment of patients with intrahepatic cholestasis. Zdorovya Ukrainy, 4, 3-4.

Ivashkin V.T., Bueverov A.O.(2009) Ratsionalnaya farmakoterapiya v gepatologii. Moskva, "Literra"293s.

Mostovyi Yu.M.(2009) Rational pharmacotherapy in hepatology. (11-nd ed.). Vinnytsia, DP “DKF”, 524s.

Perederii V.H., Tkach S.M.(2012) Practical gastroenterology. Vinnytsia, Nova knyha, $729 \mathrm{~s}$

Iurev K.L. (2012) Heptral (ademethionine) is a hepatoprotector and antidepressant. Ukrainskyi medychnyi chasopys, 1 (87), 1-11 